\title{
Feminist Jurisprudence: Grounding The Theories
}

\author{
Patricia A. Cain $\dagger$
}

\section{INTRODUCTION}

This essay originates from my participation in a workshop of the same title at the 20th National Conference on Women and the Law, held in Oakland, California in the Spring of 1989. The workshop focused on the following two questions: (1) to what extent is feminist theoretical scholarship in the field of law actually grounded in the experience of women (i.e., based on feminist method); and (2) to the extent that the theory is grounded in women's experience, does it reflect the diversity of women's experience?

Because I had recently been struggling with both of these issues, I readily accepted the invitation to participate. At the time, I hoped that my preparation for the workshop would help clarify my own thinking about the connections between feminist method and theory. My particular concern was that feminist legal theorists often ignore, or at best marginalize, lesbian experience. I call this the problem of the invisible lesbian. It is a problem that has serious consequences for the building of feminist legal theory.

What makes any theory particularly feminist is that it is derived from female experience, from a point of view contrary to the dominant male perception of reality. If feminist legal theory is derived from a feminist method uninformed by critical lesbian experience, the theory will be incomplete. Lesbian experience is essential to the formation of feminist

\footnotetext{
$\dagger$ Professor of Law, University of Texas. This essay began as a conversation with Jean Love and Leigh Leonard. Some of the resulting thoughts were tested at the Women and the Law Conference. Once the thoughts were reduced to writing, the essay and I spent a wonderful afternoon in an expanded conversation with the West Coast Fem-Crits. I am thankful to Christine Littleton and Deborah Rhode for setting up the conversation and to the following women for participating: Alison Anderson, Barbara Babcock, Martha Chamallas, Kimberle Crenshaw, Barbara Fried, Trina Grillo, Angela Harris, Jean Love, Margaret Jane Radin, Carol Sanger, Elizabeth Schneider, Reva Siegel, Nomi Stolzenberg, Nadine Taub, Stephanie Wildman, Vivian Wilson, and Zipporah Wiseman. I am also grateful for additional comments from Mary Dunlap, Anne Goldstein, Sylvia Law, Frances Olsen, and Marjorie Shultz. I have not answered fully everyone's concerns in this final draft, but I have listened and I hope the conversation will continue.
} 
theory because it stands in opposition to the institution of heterosexuality, which is a core element of male-centered reality. ${ }^{1}$ To the extent feminist legal theory seeks to challenge the male view of reality, it cannot afford to ignore lesbian experience.

The invisibility (or marginalization) of lesbian experience in feminist legal theory calls for further scrutiny. First of all, we ought to question why the invisibility is so prevalent. Second, we ought to consider what difference an eradication of that invisibility might make.

During the workshop at the Women and the Law Conference, my aim was to explore the fact of lesbian invisibility. I hoped to engage the audience in a form of consciousness-raising (CR) that would deepen their understanding of the invisibility problem and then lead to a discussion of feminist legal theory in which the centrality of lesbian experience was assumed. I was committed to consciousness-raising as my means of communication because I believe $\mathrm{CR}$ is an example of genuine feminist method. ${ }^{2}$

I think of CR as a process that occurs whenever women come together to share experiences that produce a new critical understanding of what it means to be a woman. Normally CR occurs when women gather and talk in a space that feels safe enough to explore topics that are private, topics that are rarely discussed. One does not usually think of a speech to a crowded room of 300 women as CR. Nonetheless, by telling my own and others' personal stories, followed by an invitation for critical self-reflection, my hope was to cause a shift in the level of consciousness of many women in the room. I think we succeeded. The response to my presentation, as I experienced it, was a resounding silence-a silence that I now interpret positively. Valid self-reflection, I was told by women in the audience, requires some separate space, some silence.

In this essay, I wish to continue the dialogue I began at the conference in Oakland. In Part I, I will offer some general thoughts about feminist jurisprudence, feminist method, and current trends in feminist legal scholarship. I will retell the speech from the conference workshop in Part II. While it is not an exact retelling, its focus and intent are the same. After the retelling, Part III offers time for silence and reflection. In Part IV, I focus on the problem of the invisible lesbian in feminist legal theory.

${ }^{1}$ Male homosexuality is a practice that contradicts the assumption of universal heterosexuality, but it affirms male-centered reality.

2 I agree with those theorists who suggest that the CR groups of the 1970s were engaging in uniquely feminist method. See, e.g., Women's Consciousness, WOMEN's Conscience at xiii-xvii (B.H. Andolsen, C. Gudorf and M. Pellauer eds. 1985); MacKinnon, Feminism. Marxism, Method and the State: An Agenda for Theory, 7 Signs 515 (1982) [hereinafter MacKinnon, An Agenda for Theory]; Shulman, Sexual Power: Sexual Bases of Radical Feminism, 5 SIGNS 590 (1980). 


\section{Feminist Jurisprudence, Feminist Method, and Feminist LEGAL SCHOLARSHIP}

\section{A. Feminist Jurisprudence}

The first recorded use of the phrase "feminist jurisprudence" occurred in 1978 at a conference celebrating the twenty-fifth anniversary of women graduates of the Harvard Law School. Professor Ann Scales, then a Harvard student, moderated a panel of feminist lawyers, legal educators, and judges. The question for debate was whether there was in fact, or should be, such a thing as a feminist jurisprudence. As I understand it from Professor Scales, the consensus was that there should not be.

Professor Scales, unwilling to abide by the consensus, entitled her first scholarly article Towards a Feminist Jurisprudence. ${ }^{3}$ She admitted that the risk of calling her project "feminist jurisprudence" was that the work might be misunderstood as a politically-motivated argument for special laws favoring women. Actually, she intended to question, from a feminist perspective, the completeness of a jurisprudence that is not responsive to specifically female concerns (e.g., pregnancy). ${ }^{4}$

More recently, Professor Robin West has claimed that "feminist jurisprudence is a conceptual anomaly." Existing jurisprudence is masculine, according to West, because it is about the connection between patriarchal laws and human beings, who are presumed by those laws to be male. Feminist jurisprudence cannot exist until patriarchy is abolished. ${ }^{6}$

I understand Professor West to be saying that we cannot create a complete theory of law (a jurisprudence) that is truly feminist until conditions are such that we can build the theory authentically. So long as patriarchal dominance continues, female authenticity is presumably impossible. ${ }^{7}$ As Catharine MacKinnon keeps reminding us, she (the "female") cannot articulate her own definitions now "because his foot is on her throat." 8

Without fully accepting the West/MacKinnon thesis (I believe we ${ }^{9}$

3 Scales, Towards a Feminist Jurisprudence, 56 IND. L.J. 375 (1981).

4 Id. at 375.

5 West, Jurisprudence and Gender, 55 U. CHI. L. REv. 1, 4 (1988).

6 "The virtual abolition of patriarchy is the necessary political condition for the creation of nonmasculine feminist jurisprudence." Id. at 60 .

7 West does not use the term "authenticity," but she does believe that woman has a "true subjective nature." $I d$. at 69 .

8 DuBois, Dunlap, Gilligan, MacKinnon, Menkel-Meadow, Feminist Discourse: Moral Values and the Law-A Conversation, 34 BufFalo L. REV. 11, 74-75 (1985) [hereinafter Feminist Discourse] (emphasis added).

9 In the broadest sense, I mean "we" as all women who have at some time become aware of and rebelled against the patriarchal conditions under which we live. Each act of rebellion can be viewed as a stab at freeing ourselves from the limitations of the category "woman." Rebellion (even if it is a minor form of sabotage) is self-affirming in its defiance of the inauthentic self that is thrust upon us. 
have glimpses of our own authenticity even within the patriarchy), ${ }^{10} \mathrm{I}$ do agree that we do not now have a feminist jurisprudence. We do have (and West agrees) ${ }^{11}$ feminist legal theory. ${ }^{12}$ That is, we have feminist critiques of existing (masculine) jurisprudence. ${ }^{13}$ We have examples of feminist deconstruction that uncover the male bias in the existing legal system. ${ }^{14}$ And we have feminist litigation that strives to restructure the

10 I suspect that both Professors West and MacKinnon would agree that we have such glimpses. Otherwise their own feminist projects would be subject to charges of inauthenticity or false consciousness. Indeed, West asserts that we do have glimpses of freedom from patriarchy. West, supra note 5 , at 48 . It has been reported, however, that feminists generally are not agreed on the meaning of the concept "authenticity" and further, that MacKinnon's view of the concept is that it is "unhelpful." Colker, Feminism, Sexuality, and Self: A Preliminary Inquiry into the Politics of Authenticity (Book Review), 68 B.U.L. REV. 217, 218-19 n.3, 220 n. 8 (1988).

By "authenticity" I mean individual authenticity, i.e., that which makes me uniquely me. MacKinnon's pronouncement that "authenticity" is not helpful probably reflects the fact that her critique focuses on the category "woman" and not on individual women. Indeed, the strength of her critique lies in its "group" viewpoint.

Also, I am using the term "authenticity" in a moral sense, whereas MacKinnon's critique is a political one. Her critique is one that could lead to changes in material conditions for individual women, and thereby to their attainment of individual "authenticity" in the sense of the term that $I$ intend. The relevant question to put to MacKinnon would be: Do you think the search for the authentic self is a worthwhile goal?

Although it is not my intent to develop the concept of authenticity fully in this article, some elaboration is called for. First of all, I believe that we each have an authentic self that is unique and that it is a moral goal to act in accord with that authentic self. $C f$. W. SHAKESPEARE, Hamlet Prince OF DenMaRK, I.iii.78 (W. Farnham rev. ed. 1970) (quarto 160405) ("[T]o thine own self be true ....").

Furthermore, I believe the patriarchal structure of society prevents women from attaining a sufficient concept of their individual authentic selves. In accord with this, I find it unsurprising that Kierkegaard's two categories of despair "which is conscious of being despair, as also it is conscious of being a self" are defined as (1) the despair of womanliness (despair of not willing to be oneself) and (2) the despair of manliness (despair of willing despairingly to be oneself). See S. KierkegaArd, The Sickness Unto Death 180-207 (1954).

I associate the concept of "authenticity" with other existentialists, such as Martin Heidegger and Jean Paul Sartre. Sartre, although he never developed an existentialist ethics, connected the concept of freedom with moral (authentic) choice. We are morally responsible when we choose freely and self-consciously. We act in "bad faith" when we attempt to avoid the responsibility of freedom, when we deny the existence of self as subject and instead act according to an objective role created for us-or, indeed, whenever we choose on the basis of something outside "self," including on the basis of an abstract moral principle. See $\mathbf{T}$. Lavine, From Socrates to Sartre: The Philosophic Quest 365-75 (1984).

"Authenticity," in the sense that I use it, is necessarily connected with freedom. I, as an individual woman, will have glimpses of my authenticity whenever I am freed from the category woman; that is, whenever I am able to transcend my socially constructed (and unauthentic) self.

11 West, supra note 5 , at 60.

12 Some years ago, when I first ventured to teach a feminist seminar in law, I opted to call the class "feminist legal theory" rather than "feminist jurisprudence," because the latter implied the existence of a full-fledged feminist theory of law, which I knew I did not have. I viewed the concrete creation of feminist legal theories as a move "towards a feminist jurisprudence." See Scales, supra note 3.

13 See, e.g., Minow, Foreword: Justice Engendered, 101 HaRv. L. REv. 10 (1987); Resnik, On the Bias: Feminist Reconsiderations of the Aspirations for Our Judges, 61 S. CAL. L. REV. 1877 (1988); Scales, The Emergence of Feminist Jurisprudence, 95 YALE L.J. 1373 (1986); West, supra note 5; F. Olsen, The Sex of Law (n.d.) (unpublished manuscript available from the Berkeley Women's Law Journal).

14 See, e.g., S. Estrich, Real Rape (1987); C. Mackinnon, Sexual Harassment of Working Women (1979) [hereinafter C. MacKinnon, Sexual HaRassment]; Bender, $A$ Lawyer's Primer on Feminist Theory and Tort, 38 J. LEgAl. EDUC. 3 (1988); Fineman, Domi- 
existing system. ${ }^{15}$ Thus we are moving "towards a feminist jurisprudence," 16 because the critiques and the litigation have challenged the strength of the patriarchy.

\section{B. Feminist Method}

Recent feminist legal scholarship emphasizes the importance of feminist method. ${ }^{17}$ While it is not clear whether feminist method is, in fact, limited to consciousness-raising, ${ }^{18}$ nor whether it should be, ${ }^{19}$ there does appear to be general agreement that feminist method begins with the primacy of women's experience. Listening to women and believing their stories is central to feminist method. ${ }^{20}$ If we are careful to listen to women when they describe the harms they experience as women, we are likely to get the legal theory right (i.e., perceive the problem correctly and propose the right solutions).

Consider Carol Gilligan's pathbreaking work in psychology. ${ }^{21}$ Feminist method led Gilligan to suggest new theories regarding women's

nant Discourse, Professional Language, and Legal Change in Child Custody Decisionmaking, 101 HaRv. L. ReV. 727 (1988); Finley, Transcending Equality Theory: A Way Out of the Maternity and the Workplace Debate, 86 Colum. L. REV. 1118 (1986).

15 Cases that have succeeded in changing the system include Meritor Sav. Bank v. Vinson, 477 U.S. 57 (1986) (recognizing sexual harassment as a form of sex discrimination); Roe v. Wade, 410 U.S. 113 (1973) (recognizing that a woman has a constitutionally protected interest in deciding whether to have an abortion); Reed v. Reed, 404 U.S. 71 (1971) (recognizing, for the first time, that sex classifications might violate the equal protection clause); Tomkins v. Public Serv. Elec. \& Gas Co., 568 F.2d 1044 (3d Cir. 1977) (recognizing that, at least in certain circumstances, sexual harassment violates Title VII).

16 See Scales, supra note 3. See also C. MacKinnon, Toward a Feminist Theory of The State 249 (1989) [hereinafter C. MACKInNON, FeMinist THEORY OF STATE] (arguing that current jurisprudence, both liberal and left, ignores male power, whereas feminist jurisprudence recognizes male power and calls for substantive changes that are necessary to bring about sex equality).

17 See, e.g., Bender, supra note 14; Colker, supra note 10 at 241-54; Littleton, Feminist Jurisprudence: The Difference Method Makes, 41 STAN. L. REv. 751 (1989); MacKinnon, An Agenda for Theory, supra note 2, at 519; West, The Difference in Women's Hedonic Lives: A Phenomenological Critique of Feminist Legal Theory, 3 WIS. WoMEN's L.J. 81 (1987).

18 See FEMINISM \& METHodology (S. Harding ed. 1987). In particular, see Harding, Introduction: Is There a Feminist Method?, in FEMINISM \& METHODOLOGY 1, supra, questioning whether there is a distinctive feminist method. See also Bartlett, Feminist Legal Methods, 103 HARV. L. REV. 829 (1990) (setting forth three feminist methods: (1) identifying the absence of women in the law, (2) feminist practical reasoning, and (3) consciousness-raising); Bender, supra note 14, calling for a broader approach to CR: "Consciousness-raising as a feminist practice can no longer be limited ... to women validating their own experiences in smallgroup interactions. It must be augmented by other methods of enlightening people about the pernicious effects of inbred, patriarchal institutions." Id. at 9.

19 See Bottomley, Gibson \& Meteyard, Dworkin; Which Dworkin? Taking Feminism Seriously, 14 BRIT. J.L. \& Soc'Y 47, 56 (1987), arguing that consciousness-raising is "primarily a method of empowering individual women" and thus inadequate as a complete response to patriarchy, which is a system that subjugates women as a group.

20 "Feminist method starts with the very radical act of taking women seriously ...." Littleton, supra note 17 , at 764 .

21 C. Gilligan, In a Different Voice: Psychological Theory and Women's DevelopMENT (1982). 
moral development. ${ }^{22}$ Gilligan's method was to listen to female experience as female experience-and not merely as other-than-male experience. Gilligan listened to women tell their own stories. She did not force the stories into pre-formed male categories. Because she really listened, she uncovered a "different voice" than that heard by her male colleagues.

Theories about women, however, are not always grounded on feminist method. Theories about women, even if developed by a woman, are not necessarily based on women's experience. For example, women law professors are confined to an academic environment that is particularly male. ${ }^{23}$ There is no guarantee that those of us who focus our scholarship on legal issues of concern to women will necessarily build theories based on women's experience. ${ }^{24}$ Indeed, unless we take pains to seek out women's communities, empirical data about women, and other sources of female experience, there is every risk that we will do just the opposite. $^{25}$

Catharine MacKinnon may be the feminist legal scholar who has most consistently focused on the importance of feminist method. ${ }^{26}$ Feminist method, for MacKinnon, means women listening to other women. ${ }^{27}$ Women, as they listen to each other, tend to discover a commonality of experience. $^{28}$ Uncovering the fact of women's common experiences creates new knowledge.

22 Gilligan's main thesis is that women's moral development is distinct from that of men. Women develop a morality based on an ethic of care, whereas men develop a morality based on justice, defined as an ability to rank abstract rights against each other in a hierarchical system of values. Id. at $64-105$.

23 See generally Chused, The Hiring and Retention of Minorities and Women on American Law School Faculties, 137 U. PA. L. REV. 537 (1988) (despite an increase in female full-time faculty from $13.7 \%$ in 1980 to $20 \%$ in 1986 , there are a number of disturbing trends that evidence a continuing exclusion of women from full-fledged membership in the profession).

24 See C. Heilbrun, Reinventing Womanhood (1979). In this elegant and provocative book, Carolyn Heilbrun gives us many examples of women academics who have judged other women from a male-centered perspective.

25 There is another risk for those of us cloistered away amongst the rational and the male. The risk is that, even when we do listen to women's voices, they will be the voices of women who are most like us. Thus, we must consciously seek out the stories of those who differ from us. There are many good anthologies of women's real stories that can broaden our views of life. For stories of lesbian experience, see CoMING OUT STORIES (S. Wolf \& J. Stanley eds. 1980); Lesbian Nuns: Breaking Silence (R. Curb \& N. Manahan eds. 1985). For stories of women of color, see This Bridge Called MY BACK (C. Moraga \& G. Anzaldua 2d ed. 1983). For stories that are woven together around the concept of consciousness-raising, see $A$. Shreve, Women TOGether, Women Alone (1989).

26 See Littleton, supra note 17 (reviewing MacKinnon's book, Feminism Unmodified, and crediting MacKinnon primarily for her methodological contributions to feminist jurisprudence).

27 For a full discussion of consciousness-raising as method and the relationship between method and politics, see chapters five and six of MacKinnon's most recent book. C. MACKINNON, FEMINIST THEORY OF STATE, supra note 16, at 83-125.

28 Betty Friedan, for example, chronicles the responses she received from women all over the country after the publication of her book, The Feminine Mystique, in 1963. B. FriedaN, IT Changed My Life: Writings on the Women's Movement 20-27 (1976). Anais Nin speaks of having received a similar response from women after the publication of her Diary: "When I published [the Diary] I thought it was the story of one woman. . . . But I suddenly found that my diary didn't belong to me, that it was other women's diaries too." A. NiN, A Woman SPEAKs 148 (E. Hinz ed. 1975). 
MacKinnon listened to women's common experience of sexual harassment and built a legal theory that reflected that experience. ${ }^{29}$ In May, 1975, Working Women United held a "Speak-Out" on sexual harassment. ${ }^{30}$ Women told their stories of being treated as sex objects at work. They spoke of the unarticulated job requirements for women, requirements regarding physical attractiveness and sexual availability. The organization reported that $70 \%$ of the women who responded to their survey had experienced some sexual harassment on the job. ${ }^{31}$ During this part of the 1970s, individual women also began to bring their claims regarding sexual harassment to the courts. ${ }^{32}$

MacKinnon, beginning with the data of real women's experience, ${ }^{33}$ and building on the arguments put forth by feminist litigators, developed a legal theory that characterized sexual harassment as a form of sex discrimination that ought to be covered by Title VII. A theory was necessary because existing jurisprudence did not recognize sexual harassment as a harm which the law should remedy. ${ }^{34}$ The theory revealed the male bias of the law (ignoring harms that only occur to women) and proposed a revision: a remedy for sexual harassment harms under Title VII.

\section{Feminist Legal Scholarship}

To be classified as feminist, legal scholarship should be based on women's experience. My particular concern is whether the "women's experience" that informs feminist legal theory excludes lesbian experience. I will briefly discuss what I consider to be the three stages of feminist legal scholarship ${ }^{35}$ and will review what impact, if any, lesbian experience has had on the development of each of these stages.

29 This theory is advanced in C. MacKinnon, Sexual HaRassment, supra note 14.

30 Silverman, Sexual Harassment: Working Women's Dilemma, in BuILDING FeMINIST ThEORY 84 (Longman ed. 1981).

31 Silverman, supra note 30, at 86. A subsequent survey conducted by Redbook magazine elicited 9,000 voluntary responses. Ninety percent of the respondents reported experiences of sexual harassment on the job. C. MACKINNON, Sexual HARAsSment, supra note 14, at 26.

32 See, e.g., Tomkins v. Public Serv. Elec. \& Gas Co., 568 F.2d 1044 (3d Cir. 1977); see also Taub, Book Review, 80 Colum. L. REV. 1686, 1687 (1980) (reviewing C. MACKINNON, SEXUAL HARASSMENT, supra note 14).

33 She credits her sources as including the files of Working Women United as well as individual cases of sexual harassment brought to court. C. MACKINNON, SEXUAL HARASSMENT, supra note 14 , at xiv.

34 Sexual harassment claimants lost in the original round in the lower courts, but these cases were reversed on appeal. Taub, supra note 32, at 1687. The Supreme Court finally validated the theory that sexual harassment is a harm covered under Title VII in Meritor Sav. Bank v. Vinson, 477 U.S. 57 (1986).

35 These three stages track Clare Dalton's discussion of the development of feminist legal thought in Dalton, Where We Stand: Observations on the Situation of Feminist Legal Thought, 3 Berkeley WomeN's L.J. 1 (1988). 


\section{Stage One: Formal Equality and Reproductive Rights}

The period from 1963 to 1966 is generally cited as the beginning of the modern day women's movement, sometimes described as the second wave of feminism. ${ }^{36}$ A number of important events occurred during this period. ${ }^{37}$ Betty Friedan's book, The Feminine Mystique, was published in 1963. The same year, the Equal Pay Act was enacted. ${ }^{38}$ In 1964, Title VII $^{39}$ was enacted, prohibiting sex discrimination in employment. Both statutes exhibit a commitment to the principle of equal opportunity. However, early evidence indicated that the Equal Employment Opportunity Commission was less than fully committed to the principle as applied to women. ${ }^{40}$ For example, in 1965, the Commission ruled that employers could employ sex-segregated advertising, despite the clear statutory language to the contrary. ${ }^{41}$ In response, a new national women's activist group was formed in 1966, the National Organization for Women (NOW). ${ }^{42}$

In the beginning, NOW's agenda focused on formal equality in the public arena. ${ }^{43}$ The organization avoided issues concerning sexual and reproductive freedom. ${ }^{44}$ Some members became concerned when NOW began to consider supporting abortion rights. They split off and formed the Women's Equity Action League (WEAL). ${ }^{45}$ NOW adopted a proabortion stance shortly thereafter. ${ }^{46}$ However, its leaders found the issue of lesbianism to be more problematic. ${ }^{47}$ Lesbian feminists who "came out" in the early days of the movement were "disinherited" by their sis-

36 The first wave of feminism occurred at the end of the 19th century and marks the beginning of the women's movement. Some writers speak of the women's movement as though it began in the $1960 \mathrm{~s}$, thereby distorting history and ignoring a much longer feminist tradition. The goals accomplished in the first wave included the passage of married women's property acts and the enactment of the 19th amendment granting women suffrage. For a good, yet brief, discussion of feminist history (herstory), see Bender, supra note 14, at 12-15.

37 Although the modern women's movement owes much to the first wave of feminism, it also owes much to the civil rights and the peace movements of the late 1950 s and the 1960 s. See generally S. EVANS, BORN FOR LIBERTY 263-85 (1989).

38 Equal Pay Act of 1963, 29 U.S.C. $\$ 206$ (1982).

39 Civil Rights Act of 1964, 42 U.S.C. $\S 1981$ (1982).

40 "EEOC commissioners and staff ... expressed a general belief that the addition of sex to the law had been illegitimate-merely a ploy to kill the bill-and that it did not therefore constitute a mandate to equalize women's employment opportunities." C. Harrison, ON Account of Sex: The Politics of Women's Issues 1945-1968, at 187 (1988).

41 Id. at 188 .

42 Id. at 192-93. See also S. EVANS, supra note 37, at 277.

43 "The purpose of NOW is to take action to bring women into full participation in the mainstream of American society now, exercising all the privileges and responsibilities thereof in truly equal partnership with men." Nat'l Organization for Women, Statement of Purpose, reprinted in B. FRIEDAN, supra note 28 , at 87.

44 C. HARRISON, supra note 40, at 198-99.

45 S. Evans, supra note 37 , at 278.

46 B. FrIEDAN, supra note 28 , at $120-22$.

47 See id. at 159. (At a 1970 national feminist demonstration at which participants were asked to wear lavender lesbian armbands as a symbol of solidarity, Friedan refused. "For me . . . the women's movement . . . had nothing whatsoever to do with lesbianism.") 
ters. ${ }^{48}$ In the mainstream of the movement, the word "lesbian" was shunned. ${ }^{49}$

In the late 1960s, as the modern women's movement rallied together and began to litigate for women's equality, fewer than 5\% of all lawyers were women and fewer than $2 \%$ of all law professors were women. ${ }^{50}$ Feminist legal scholarship during this period, to the extent it existed at all, ${ }^{51}$ reflected the goals of the concurrent women's movement. Such scholarship tended to focus on equality in the public sphere and to argue that women should be treated the same as men. ${ }^{52}$

Feminists who were concerned with reproductive freedom necessarily had to deal with the ways in which women were different from men. However, much early feminist legal scholarship was written from a viewpoint that implicitly approved the male norm. ${ }^{53}$ Specific concern for lesbian issues is missing from this scholarship. To the extent lesbians are no different from heterosexual women, they were, of course, silently included in the fight for equality. ${ }^{54}$ But the differences between the experience of lesbians and heterosexual women were irrelevant in the fashioning of feminist legal theory during Stage One.

\section{Stage Two: Women Are Different from Men}

Once women began to be treated like men, people began to notice that women really are not like men. Women are most noticeably not like men when they are pregnant. Stage Two theorists began to develop theories of equality that could account for certain differences between women

48 S. EVANS, supra note 37, at 294. See generally LESBIANISM AND THE WOMEN'S MoveMENT (N. Myron \& C. Bunch eds. 1975).

49 NOW was the organization at the center of the women's movement and although its membership included many active lesbians, the organization itself consciously avoided lesbian issues in the early days. Such homophobic attitudes appear to have been worse on the East Coast than on the West Coast. See D. Martin \& P. Lyon, Lesbian Woman 256-76 (1972).

50 Fossum, Women Law Professors, 1980 AM. B. Found. REs. J. 903, 906.

51 In checking the Index to Legal Periodicals for 1967-70, I found only 36 entries under the heading "Women." IndeX to Legal Periodicals SePtember 1967 - August 1970, at 849 (M. Russell \& G. Meyer eds. 1971). In the 1970-73 volume, there were over 100 entries under "Women." Index to Legal Periodicals SePTember 1970 - AuguST 1973, at 953 55 (G. Meyer ed. 1974).

52 See, e.g., Epstein, The Docile Majority: Bridging the Gap, 25 RUTGERS L. REV. 12 (1970); Sassower, The Legal Profession and Women's Rights, 25 Rutgers L. Rev. 54 (1970). Some of the significant early work regarding women was done by male academics. See L. Kanowitz, Women and THE LAW-The Unfinished Revolution (1969); White, Women in the Law, 65 Mich. L. REV. 1051 (1967).

53 For a critique of equality theory on the grounds that it accepts the male norm, see Finley, supra note 14.

54 Lesbians differed from heterosexual women in one very noticeable respect, however. Lesbians were denied custody of their children because they were deemed unfit mothers. Thus, there is some early separate lesbian-feminist scholarship on custody. See, e.g., Hunter \& Polikoff, Custody Rights of Lesbians, 25 Buffalo L. REV. 691 (1976); Hitchens \& Price, Trial Strategy in Lesbian Mother Custody Cases: The Use of Expert Testimony, 9 GoldEN GATE U.L. REV. 451 (1978-79). 
and men. ${ }^{55}$ At a minimum, they argued, equality theory should account for the fact that women get pregnant. ${ }^{56}$ Lesbians are as biologically different from men as heterosexual women are. ${ }^{57}$ Thus, while the focus on difference remained limited to biological differences between women and men, lesbian experience had no special insights to offer.

Some theorists in Stage Two have suggested that women are different from men in ways that go beyond biology. Some cultural feminists, ${ }^{58}$ for example, have claimed that the experience of mothering results in social and psychological gender differences. ${ }^{59}$ Women, because they give birth and nurture, tend to be more connected and caring than men.

Following the lead of Carol Gilligan, some feminist legal theorists began to focus on ways that woman's "different voice" has been ignored by the law. They pointed out that, because the law is masculine, it reflects values of autonomy rather than connection and caring. ${ }^{60}$ Then they argued that the law should recognize and protect specifically female values. ${ }^{61}$

Catharine MacKinnon, another Stage Two legal theorist, ${ }^{62}$ also has

55 See generally Kay, Equality and Difference: The Case of Pregnancy, 1 BERKELEY WoMEN's L.J. 1 (1985); Law, Rethinking Sex and the Constitution, 132 U. PA. L. REV. 955 (1984); Wildman, The Legitimation of Sex Discrimination: A Critical Response to Supreme Court Jurisprudence, 63 OR. L. REV. 265 (1984); Williams, The Equality Crisis: Some Reflections on Culture, Courts, and Feminism, 8 WoMEN's RTS. L. REP. 175 (1982).

56 This was the thesis of Ann Scales' first article. Scales, supra note 3.

57 The risk of pregnancy is lower for lesbians, of course. And, statistically, fewer lesbians get pregnant (while they are lesbians) than heterosexual women. Thus, accommodation for pregnancy, although relevant for some lesbians, has never been at the top of the lesbian agenda.

58 By "cultural feminist," I mean (loosely) those feminists who recognize the existence of a separate women's culture, which has values that ought to be reclaimed from the patriarchy. See generally Alison Jaggar's discussion of the politics of radical feminism, which focuses on the reinterpretations and re-conceptions of value by feminists who recognize how women's culture has been devalued by the patriarchy. A. JAGgar, Feminist Politics AND Human Nature 249-55 (1983).

Robin West uses the term "cultural feminist" to include those feminists who believe that "the important difference between men and women is that women raise children and men don't." West, supra note 5, at 13. Thus, her use of the term is narrower than my understanding of the term. See infra notes 69-74 and accompanying text.

59 See, e.g., Kuykendall, Toward an Ethic of Nurturance: Luce Irigaray on Mothering and Power, in Mothering: EsSAYS IN Feminist Theory 263 (J. Trebilcot ed. 1984); Ruddick, Maternal Thinking, in MotherING: ESSAYS IN FEMINIST THEORY 213 (J. Trebilcot ed. 1984).

60 See West, supra note 5, at 1. West's claim that the law does not recognize harms that stem from the connected experiences of women is not totally true. Tort claims for loss of consortium are discussed by modern day courts in terms of injury to the relationship. See, e.g., Rodriguez v. Bethlehem Steel Corp., 12 Cal. 3d 382, 525 P.2d 669, 115 Cal. Rptr. 765 (1974). Of course, early recognition of such claims occurred in the days when wives were viewed as the property of their husbands. Thus, the theoretical basis for early claims was property damage rather than relational harm. See M. Chamallas \& L. Kerber, Women, Mothers AND the Law of Fright: A History 5-6 (Legal History Program Working Papers Series 3, March 1989).

61 Leslie Bender asks, for example, "Why . . . do tort damages recognize financial loss and yet remain reluctant to recognize relational loss . . . ?" Bender, supra note 14, at 37.

62 I include in "Stage Two" all theorists who reject the liberal feminist approach of "Stage One," but do not (yet) embrace postmodernism. (See discussion of Stage Three infra pp. 204-05.) Because I do embrace postmodernism to the extent it eschews essentialism, universality, and the limits of categorization, I am wary of the categorization I create by placing theorists into 
argued that men and women are different, but the difference is that men dominate and women are subordinate. ${ }^{63}$ Which came first, dominance or difference, is an unimportant question, in her view. The important thing is to end the dominance. ${ }^{64}$ Legal arguments that pose the issue as one of difference between the sexes are not likely to end the dominance. MacKinnon calls for a paradigm shift, away from differences in biology, differences in experience, differences in essence, to the only difference that really matters: the difference in power. Her "inequality" approach to sex discrimination recognizes the imbalance in power between men and women. "Practices which express and reinforce the social inequality of women to men are clear cases of sex-based discrimination ...."65 Sexual harassment is one such practice. ${ }^{66}$

One might expect cultural feminists and dominance theorists who engage in legal scholarship (such as Gilligan and MacKinnon, respectively) to acknowledge the relevance of lesbian experience in their writings. It is particularly surprising to discover the invisible lesbian problem in the work of cultural feminists. In disciplines other than law, feminist theorists working to reclaim women's culture and its values have often focused on lesbian community. ${ }^{67}$ But in legal scholarship, discussions of female value focus on "woman as mother."68

Robin West's article, Jurisprudence and Gender, ${ }^{69}$ is a prime example of the problem. West posits that current (masculine) jurisprudence is based on the concept of human beings as separate from each other and that this "separation thesis" forms the core of both liberal and critical male legal theories. Feminist theory, in contrast, views human beings as primarily connected to one another. Both cultural and radical feminists use this "connection thesis." West begins her article with four examples of women's primary and material experience with connection: (1) pregnancy; (2) heterosexual penetration; (3) menstruation; and (4) breastfeeding. ${ }^{70}$ Despite West's awareness of the pressure on all women to be heterosexual," her list of "connection" experiences ignores specifically lesbian experiences of "connection."

what appear to be separate stages of feminist scholarship. I ask the reader to imagine the boundaries as more fluid than my brief identification of the categories/stages suggests.

63 C. MacKinnon, Feminism Unmodified, 32-45 (1987).

64 "[O]n the first day that matters, dominance was achieved . . . ." Id. at 40.

65 C. Mackinnon, SeXual Harassment, supra note 14, at 174.

66 Id.

67 See generally A. JAGGAR, supra note 58, at 249-302 and sources cited therein. In the field of philosophy, there are works that build ethical theory on women's bonding to other women. See, e.g., J. Raymond, A Passion for Friends: Toward a Philosophy of Female Affection (1986); S. Hoagland, Lesbian Ethics: Toward New Value (1988).

68 Here, I mean mother in the broad social sense as a person who is nurturing and selfsacrificing.

69 West, supra note 5.

70 Id. at 3.

71 "Most women are indeed forced into motherhood and heterosexuality." Id. at 71. 
Furthermore, West's two categories of feminist thought, cultural and radical, are constructed in such a way as to exclude lesbian feminists. West defines cultural feminists as those who focus on the mother-child connection as the source of women's greater capacity for caring and nurturance. Professor West does not necessarily align herself with these cultural feminists. ${ }^{72}$ But I worry that in creating her two categories of feminists (cultural feminists and radical/dominance feminists), she ignores those lesbian feminists who are attempting to develop women's community (connections to other women $)^{73}$ and to reclaim feminist value as encompassing both separation and connection. ${ }^{74}$

Dominance theorists also tend to ignore lesbian experience. Catharine MacKinnon, for example, has argued that women are constantly and always subordinated to men. ${ }^{75}$ In MacKinnon's view, any special abilities for caring and connection come, not from the positive aspects of motherhood, but from the negative aspects of subordination. ${ }^{76}$ Women build webs of connection to survive the subordination. "Women value care because men have valued us according to the care we give them ,77

To the claim that lesbian experience is different, that lesbians are not subordinate to men, that their care is not male-directed, MacKinnon appears to have two different responses. Her first response is that exceptions do not matter. MacKinnon's intent is to offer a critique of the structural condition of women as sexual subordinates and not to make existential claims about all women. ${ }^{78}$ It does not affect her theory that all women are not always subordinated to men. ${ }^{79}$ Thus, for MacKinnon, lesbian experience of non-subordination is simply irrelevant.

Her second response is more troubling. It goes beyond the assertion that lesbian experience is irrelevant; it denies the claim that lesbian experience is free from male domination.

Some have argued that lesbian sexuality-meaning here simply women having sex with women, not with men-solves the problem of gender by

72 Although she does not include herself in the list of legal scholars who have engaged in "cultural feminist" projects, she explains her "connection thesis," as applied to women, in terms of women's biological connection to pregnancy. Thus, West has been described by Joan Williams as a "biological determinist." Williams, Deconstructing Gender, 87 MICH. L. REV. 797, 800 n. 11 (1989).

73 See, e.g., M. Daly, Pure LuSt (1984); M. Daly, Gyn/Ecology (1978).

74 See, e.g., S. HoAGLAND, supra note 67.

75 "[I]f you look at ... whether women have ever not been subordinate to men, ... as I see it, if bottom is bottom then look on the bottom, and there is where women will be." Feminist Discourse, supra note 8, at 71 .

76 C. MacKinnon, Feminism Unmodified, supra note 63, at 39; Feminist Discourse, supra note 8 , at 74 .

77 C. MACKINNON, FEMINISM UNMODIFIED, supra note 63, at 39.

78 See, e.g., C. MACKInNon, FEMINiSM UNMODIFIED, supra note 63 at 55-56, 305-06 n.6.

79 "Structural truths about the meaning of gender may or may not produce big numbers. . . [T]o say 'not all woman [sic] experience that,' as if that contraindicates sex specificity, .... is to suggest that to be sex-specific, something must be true of 100 percent of the sex affected." $C$. MACKINNON, FEMINISM UNMODIFIED, supra note 63, at 55. 
eliminating men from women's voluntary sexual encounters. Yet women's sexuality remains constructed under conditions of male supremacy; women remain socially defined as women in relation to men; the definition of women as men's inferiors remains sexual even if not heterosexual, whether men are present at the time or not. ${ }^{80}$

I find this passage objectionable for several reasons. My primary objection is that MacKinnon has defined lesbian sexuality to suit her purposes ("simply women having sex with women"-i.e., with nothing else changed except that a woman replaces a man). Although I do not dispute that lesbian couples can sometimes ape their heterosexual counterparts, I am infuriated by MacKinnon's silencing of the rest of lesbian experience. Where is MacKinnon's feminist method? To whom does she choose to listen? Would it not enrich her theory to recognize the reality of non-subordination that some lesbians claim as their experiential reality and ask about its relevance to her underlying theory? ${ }^{81}$ And yet, because her theory is premised on a single commonality among women, sexual subordination, MacKinnon fails to see the relevance of the lesbian claim to non-domination, even when it stands-literally-in front of her. ${ }^{82}$

The exclusion of lesbian experience from feminist legal theory is also documented in Clare Dalton's recent summary of feminist legal thought. ${ }^{83}$ Dalton describes present aspirations to feminist jurisprudence as falling within two camps: "woman as mother" theories and "woman as sexual subordinate" theories. ${ }^{84}$ Neither camp embraces lesbian experience as central to the formation of theory. I suspect Professor Dalton's description is accurate. I can find no major "theory piece" by a legal scholar that focuses on the experience of adult women loving each other

80 C. Mackinnon, Feminist Theory of State, supra note 16, at 141-42 (footnote omitted).

81 For example, the image of the lesbian in the dominant culture is that of a masculine, often predatory, character, the "butch" of the butch-femme lesbian couple. MacKinnon's references to lesbians often reinforce this stereotype. See, e.g., C. MacKinnon, Feminist TheORY OF STATE, supra note 16, at 119 (lesbian sex does not necessarily transcend the "erotization of dominance and submission"); C. MACKInNON, SExual HaRAsSMENT, supra note 14, at 206 (positing a lesbian harasser). I believe MacKinnon does herself (as well as lesbians) a disservice by not acknowledging the reality of co-equal relationships that many lesbians experience. Indeed, the extreme dissonance between traditional male-created concepts of lesbian existence and the reality of much lesbian existence tells us that the patriarchy has constructed lesbianism in a way that supports its norm of enforced heterosexuality. Although MacKinnon recognizes this patriarchal response to lesbianism ("[l]esbians can so violate the sexuality implicit in female gender stereotypes as not to be considered women at all," id. at 110), she never reveals an understanding of lesbian existence different from the patriarchal image of the "butch."

82 I mean this statement literally. Mary Dunlap, a lesbian lawyer, was on a panel at the Buffalo Law School with MacKinnon (and others), entitled "Feminist Discourse, Moral Values and the Law." Responding to MacKinnon's view of "woman," silenced by "man's" foot on her throat, Dunlap rose and said: "I am a woman standing ... [and] I am not subordinate to any man." MacKinnon failed to acknowledge the potential relevance of Dunlap's life experience as a lesbian to her claim of non-subordination. See infra pp. 211-12; see also C. MACKINNon, FEMINISM UNMODIFIED, supra note 63, at 221, 305-06 n.6.

83 Dalton, supra note 35.

84 These two camps parallel Robin West's prior categorization of feminists as either cultural or radical. West, supra note 5 . 
as the core experience for building a legal theory premised on caring and connection. ${ }^{85}$ And although "woman as sexual subordinate" theorists ${ }^{86}$ are more likely to acknowledge the fact of lesbian existence, ${ }^{87}$ they focius on a critique of male dominance rather than on lesbian bonding as a possible alternative to male dominance. ${ }^{88}$

\section{Stage Three: Postmodernism}

Borrowing from Clare Dalton, I call the third stage of feminist legal theory "postmodernism." 89 Postmodern thought challenges notions such as objectivity and universality. The postmodern "knowing self" is subjective, concrete and particular, constructed through the lived experiences of the subject.

Postmodern feminism is generally associated with French feminists, such as Helene Cixous, Luce Irigaray, and Julia Kristeva. ${ }^{90}$ The influence of Simone de Beauvoir's work ${ }^{91}$ on these theorists is evident. ${ }^{92}$ Beauvoir's existential analysis of woman as "other" is conceived by postmodern feminists as enabling women to critique the dominant culture. Being "other" allows women to understand "plurality, diversity, and difference." 93

From a postmodern perspective, feminist theory is inadequate when limited by the perception that there is one essential commonality among all women. Cultural feminists who focus on "woman" solely as "mother" (actual or cultural) do not speak to the full complexity of female experience. Radical feminists, such as MacKinnon, who focus on "woman" solely as "sexual subordinate" also speak limited truths. ${ }^{94}$ Good feminist theory ought to reflect the real differences in women's

85 But see Reese, The Forgotten Sex: Lesbians, Liberation, and the Law, 11 WILlameTte L.J. 354 (1975) (lesbian-centered critique of areas of the law that ignore the existence of lesbians).

86 E.g., Catharine MacKinnon. See, e.g., C. MACKInNon, Feminism UNModified, supra note 63.

87 See C. MAcKinnon, Feminist Theory of State, supra note 16, at 119; C. MAcKinnon, SeXual Harassment, supra note 14, at 206. MacKinnon claims that a feminist jurisprudence would recognize that the question of gay and lesbian rights is a question of sex equality rights. C. MACKInNON, Feminist Theory of STATE, supra note 16, at 248. Unfortunately, she does not elaborate on this point other than to articulate the connection between discrimination based on sexuality and discrimination based on gender, a connection that is at the core of her theory.

88 See, e.g., C. MacKinnon, Sexual Harassment, supra note 14, at 203-06 (discussing sexual harassment of gay and lesbian employees).

89 Dalton, supra note 35.

90 For an excellent overview of postmodern feminism, and of these three French theorists in particular, see R. TONG, FEMINIST Thought: A CoMPrehensive INTRODUCTION 217-33 (1989).

91 S. DE Beauvoir, The Second Sex (1952).

92 They have also been influenced by Jacques Derrida and Jacques Lacan. R. ToNG, supra note 90 , at $219-23$.

93 Id. at 219.

94 See Dalton, supra note 35 , at $7-8$. 
realities, in our lived experiences. These include differences of race, ${ }^{95}$ class, age, physical ability, and sexual preference.

Postmodern legal theorists will want to reject the limitations caused by any categorization. Although they will want to listen to the reality of lesbian experience, these theorists will not be inclined to build a grand theory based on the concept of "woman" as "lesbian." In the final part of this essay, I offer some thoughts about the potential relevance of lesbian experience to the postmodern development of feminist legal theory.

\section{THE RETELling}

I believe that current feminist legal theory is deficient and impoverished because it has not paid sufficient attention to the real life experiences of women who do not speak the "dominant discourse."96 Elsewhere I have urged that feminist law teaching ought to include "listening to difference" and "making connections." "97 Here I urge the same for feminist legal scholarship.

Most feminist legal theorists, by focusing on sameness and difference, have fallen into either the assimilationist trap (all women are the same as men/all women are the same) or the essentialist trap (all women are different from men in one essential way/all women are different, but what counts is their essential commonality). The only difference between assimilationists and essentialists is that the former ignore the reality of differences whereas the latter say that differences generally do not matter. The two concepts, assimilationism and essentialism, collapse into each other to the extent they treat women as a single class that is essentially the same.

Elizabeth Spelman describes the essentialist's solution to the "differences" problem in feminist theory: "The way to give proper significance to differences among women is to say that such differences simply are less significant than what women have in common. This solution is very neat, for it acknowledges differences among women only enough to bury them." 98 The difficulty arises when an individual essentialist theorist

95 For an especially good critique of the failure of feminist legal theorists to acknowledge and understand the difference that race makes, see Harris, Race and Essentialism in Feminist Legal Theory, 42 STANFORD L. REV. 581 (1990).

96 I borrow the phrase "dominant discourse" from Martha Fineman, who argues that current theories of child custody are shaped by the "dominant discourse," a discourse which excludes the mother's experience. Fineman, supra note 14, at 730 . Ironically, I am rebelling against a "dominant discourse" that privileges the experience of motherhood over other experiences of female connections. See also West, supra note 5 , at 28 , claiming that cultural feminism, which focuses on the mother-child connection, is "our dominant feminist dogma."

97 Cain, Teaching Feminist Legal Theory at Texas: Listening to Difference and Exploring Connections, $38 \mathrm{~J}$. OF LEGAL. EDUc. 165 (1988). See id. at 171, explaining that if students will listen to each other in a way that encourages identification rather than contrast, then they will "connect" in ways that lead to deeper understanding.

98 Spelman recognizes the limitations of this solution, concluding, "But it doesn't bury them very 
must determine the content of this commonality which is so significant that it trumps differences. When white, straight, economically-privileged feminists name the commonality, and ignore differences, the result may be that all women are assimilated into a single class of white, straight, middle-class women.

It is not enough to name the differences of race, class, and sexuality. The differences need to be understood. Much recent feminist legal scholarship includes the perfunctory footnote, dropped the first time the essential category "woman" is mentioned, which acknowledges the differences of race and class, and sometimes of sexual preference. Such politically correct footnotes name the differences, but I see no evidence in the accompanying texts that the differences matter. Scholarship that nominally recognizes differences, but still categorizes "woman" from a single perspective is stuck in the assimilationist/essentialist trap.

I do not mean to ignore the importance of our commonalities. It is valuable to identify the similarities among all women. When we identify what we have in common, we begin to build bridges and connections. Yet if we ignore the differences, we risk distorting those connections, because any connection that fails to recognize differences is not a connection to the whole of the other self. A normative principle that honors only what I have in common with each of you fails to respect each of you for the individual woman that you are. To respect you, despite your difference, is an insult. Such respect is not respect for your difference, but only for our sameness. Such respect belittles your difference and says it does not matter. Such "respect" falls into the assimilationist/essentialist trap.

Let me give you an example. A white law professor says to her Black female colleague: "Sometimes I forget that you are Black. Sometimes I think of you as white." 99 The comment is meant as a compliment, but it denies the real life experience of the Black woman to whom it is addressed. It says, ultimately, "what I respect in you is only what you have in common with me."

Now let me give you an example out of lesbian experience. A lesbian college teacher proposes a course entitled "The Outsider in Twenti-

effectively." E. Spelman, Inessential Woman: Problems of Exclusion in Feminist THOUGHT 3 (1988).

99 This story comes most recently from Pat Williams, although I have heard it from other persons of color. Remarks by Pat Williams, Critical Legal Studies Conference on Feminism, Pine Manor, Massachusetts (June 1985). I also have white friends who have made similar observations to me about persons of color.

Fran Olsen tells me that in 1960 at a Quaker peace camp, they sang the following song: Oh, there'll be no distinction there;

No, there'll be no distinction there.

We'll all be white

In that heavenly light;

There'll be no distinction there.

Letter from Frances Olsen to Patricia Cain (July 19, 1989). 
eth-Century American Literature." The course is to include writings of lesbians and gay men, as well as other outsiders, such as persons who have been in mental institutions or prisons. In discussing the potential course, the teacher's (presumably) heterosexual colleagues dismiss the notion that an author's sexuality might be an important aspect of her or his writing, claiming that sexuality is no different from "a thousand other things" that might influence the writer. ${ }^{100}$ None of the teacher's colleagues considers "having to live as a 'different' person in a heterosexist culture" 101 as a factor important to one's writing.

Adrienne Rich, a lesbian poet, echoes the same theme in the following story:

Two friends of mine, both artists, wrote me about reading the "TwentyOne Love Poems" with their male lovers, assuring me how "universal" the poems were. I found myself angered, and when I asked myself why, I realized that it was anger at having my work essentially assimilated and stripped of its meaning, "integrated" into heterosexual romance. That kind of "acceptance" of the book seems to me a refusal of its deepest implications. The longing to simplify . . to assimilate lesbian experience by saying that "relationship" is really all the same, love is always diffieult-I see that as a denial, a kind of resistance, a refusal to read and hear what I've actually written, to acknowledge what I am. ${ }^{102}$

There is a commonality between Adrienne Rich and her heterosexual artist friends. They all experience love and relationship. Yet even if some portion of the love experience is universal, the heterosexual world will never understand the gay and lesbian world if we all focus on the commonality, the universal. To claim that lesbians are the same as heterosexual women or that Black women are the same as white women is to fall into the assimilationist/essentialist trap. Such claims deny the reality of our differences by ignoring or discounting them. Yet it is not enough to recognize and name the differences among us as women. We must also understand those differences.

I ask those of you in the audience who are heterosexual to focus on an important love relationship in your life. This could be a present relationship or a past one, or even the relationship you hope to have. I ask you: how would you feel about this relationship if it had to be kept utterly secret? Would you feel "at one with the world" if a slight mistake in language ("we" instead of "I") could lead to alienation from your friends and family, loss of your job? Would you feel at one with your lover if the only time you could touch or look into each other's eyes was in your own home-with the curtains drawn? What would such selfconsciousness do to your relationship?

100 Bulkin, 'Kissing/Against the Light': A Look at Lesbian Poetry, in LesBian STudies 40-41 (M. Cruikshank ed. 1982).

101 Id. (quoting Adrienne Rich).

102 An Interview with Adrienne Rich, quoted in Bulkin, supra note 100, at 44-45. 
I use the following exercise to demonstrate to my students our different points of view. First I ask each student to write down three selfdescriptive nouns or adjectives, to name three aspects of her (or his) personal self. ${ }^{103}$ When they have finished writing, we go around the room and each student reads the three choices aloud. For my women students, the list almost always includes either the word woman or female. Thus, we share a perception of self as female. The meaning of female may vary, but it is significant that we all view the fact that we are women as one of the three most important facts about ourselves.

As to the rest of the list, there are important differences. For example, no white woman ever mentions race, whereas every woman of color does. Similarly, straight women do not include "heterosexual" as one of the adjectives on their lists, whereas lesbians, who are open, always include "lesbian" as one of the words on their lists. The point is, not only are we different from each other in such obvious ways as race and sexuality, but we perceive our differences differently.

The results of my exercise are not surprising. Because of the pervasive influences of sexism, racism, and heterosexism, white, heterosexual women think of gender as something that sets them apart, as something that defines them, whereas neither race nor sexuality seems to matter much. Yet if neither race nor sexuality matters much to a white, heterosexual woman, how can she begin to understand the ways in which it matters to others who are different from her in these dimensions?

I wonder sometimes whether heterosexual women really understand the role that heterosexuality plays in the maintenance of patriarchy. Indeed, I sometimes wonder whether lesbians really understand. And yet, if feminist legal theory is to provide meaningful guidance for the abolition of patriarchy, feminist theorists must understand heterosexuality as an institution and not merely as the dominant form of sexuality.

Adrienne Rich illuminated the problem years ago in her brilliant critique of heterosexuality: ${ }^{104}$

[I]t is not enough for feminist thought that specifically lesbian texts exist. Any theory or cultural/political creation that treats lesbian existence as a marginal or less 'natural' phenomenon, as mere 'sexual preference,' or as the mirror image of either heterosexual or male homosexual relations, is profoundly weakened thereby ....

...

... Feminist research and theory that contributes to lesbian invisibility or marginality is actually working against the liberation and empowerment of woman as a group. ${ }^{105}$

Adrienne Rich encourages us to look at heterosexuality from a new

103 I do this in my feminist legal theory class. Most of the students are women.

104 Rich, Compulsory Heterosexuality and Lesbian Existence, 5 SIGNS 631 (1980).

105 Id. at $632,647-48$ (footnote omitted). 
perspective, from the perspective of the "lesbian possibility." The invisibility of lesbian existence, however, removes the lesbian possibility from view. If there are no lesbians, the only possibility is heterosexuality. Men will assume all women are equally available as sex partners. Women will choose men and never question that choice.

If the choice is never questioned, can it be an authentic choice? Do heterosexual women really choose men or are they victims of false consciousness? And if they are victims of false consciousness, then how do we know that most women are heterosexual? Might they not choose otherwise if they were truly free to choose? ${ }^{106}$

Marilyn Frye offers a challenge to feminist academics and I want to echo her in repeating it here for feminist legal theorists:

I want to ask heterosexual academic feminists to do some hard analytical and reflective work. To begin with, I want to say to them:

I wish you would notice that you are heterosexual.

I wish you would grow to the understanding that you choose heterosexuality.

I would like you to rise each morning and know that you are heterosexual and that you choose to be heterosexual - that you are and choose to be a member of a privileged and dominant class, one of your privileges being not to notice.

I wish you would stop and seriously consider, as a broad and longterm feminist political strategy, the conversion of women to a womanidentified and woman-directed sexuality ... ${ }^{107}$

Frye reports that a typical response by heterosexual women to such inquiries is that, although they may understand what she is saying, they cannot just up and decide to be lesbian. ${ }^{108} \mathrm{I}$, too, have women colleagues and friends who similarly respond, with a shake of the head, that they are hopelessly heterosexual, that they just are not sexually attracted to women.

Frye says that she wants to ask such women (and so do I), "Why not? Why don't women turn you on? Why aren't you attracted to women?" 109 These are serious questions. Frye encourages heterosexual women to consider the origins of their sexual orientation:

The suppression of lesbian feeling, sensibility, and response has been so thorough and so brutal for such a long time, that if there were not a strong and widespread inclination to lesbianism, it would have been erased from human life. There is so much pressure on women to be heterosexual, and this pressure is both so pervasive and so completely denied, that I think

\footnotetext{
106 Rich asks why, "[i]f women are the earliest sources of emotional caring and physical nurture for both female and male children, ... the search for love and tenderness in both sexes does not originally lead toward women ..... Id. at 637 .

107 Frye, A Lesbian Perspective on Women's Studies, in Lesbian Studies 194, 196 (M. Cruikshank ed. 1982).

108 Id.

109 Id.
} 
heterosexuality cannot come naturally to many women; I think that widespread heterosexuality among women is a highly artificial product of the patriarchy.... I want heterosexual women to do intense and serious consciousness-raising and exploration of their own personal histories and to find out how and when in their own development the separation of women from the erotic came about for them. I would like heterosexual women to be as actively curious about how and why and when they became heterosexual as I have been about how and why and when I became lesbian. ${ }^{110}$

\section{SILENCE}

Engage in self-reflection.

[Did she really mean that? Am I supposed to sit here and consider lesbianism as a possibility? ... Why not? . . . And if I do consider it, but choose men anyway, is my choice more authentic? What about tomorrow? Do I choose again?]

[She doesn't understand. I did choose. Twenty years ago I chose for the children. Does that make my choice inauthentic? What does my choice mean for me today?]

[What about those of us who choose to live alone, who reject intimacy altogether? Am I choosing to be lesbian if I reject men or only if I choose women? As a woman alone, how am I perceived?]

[To take lesbianism seriously, do I have to reject men? Can I choose both women and men?]

[What is all this about choice? I've been a lesbian all my life. I never chose it. I've just lived my life as it was.]

\section{Connections}

The most consistent feminist claim, at least since the publication of Simone de Beauvoir's The Second Sex, is that knowledge of reality has been constructed from a male-centered standpoint. From their position as outsider, women have questioned that reality, because women's life experiences differ-often dramatically-from those of men. The most cohesive and challenging critiques of male-centered reality have been made by women from standpoints that are exactly opposite, experientially, from those of men. ${ }^{11}$ One such critique is made by cultural feminists from the "woman as mother" standpoint. Another is made by other radical feminists from the "woman as sexual subordinate" standpoint.

110 Id. at 196-97.

111 See, e.g., Hartsock, The Feminist Standpoint: Developing the Ground for a Specifically Feminist Historical Materialism, in Discovering ReAliTY 283-310 (S. Harding \& M. Hintikka eds. 1983), arguing that the material differences in men and women's lives determine their relative abilities to see reality. 
The fact that so many women can identify common life experiences that are ignored by the male version of reality makes any critique based on such common experiences compelling and powerful. But theorists ought to resist transforming a critical standpoint into a new all-encompassing version of reality. Indeed, my fear is that what started as a useful critique of one privileged (male) view of reality may become a substitute claim for a different privileged (female) view of reality.

Catharine MacKinnon, for example, critiques the patriarchy from a "woman as sexual subordinate" standpoint. As compelling as her critique is, it should not be viewed as the one and only existential reality for women. And yet MacKinnon herself is so committed to this standpoint that she sometimes seems to claim it as the only reality for women. ${ }^{112}$

MacKinnon's theory is that woman's subordination is universal and constant, but not necessarily inevitable. ${ }^{113}$ She cautions against building theory on the basis of Carol Gilligan's discovery of woman's "different voice" because the women Gilligan listened to were all victims of the patriarchy. Thus, MacKinnon is wary of assigning value to their moral voice. As she explains,

[b]y establishing that women reason differently from men on moral questions, [Gilligan] revalues that which has accurately distinguished women from men by making it seem as though women's moral reasoning is somehow women's, rather than what male supremacy has attributed to women for its own use. When difference means dominance as it does with gender, for women to affirm differences is to affirm the qualities and characteristics of powerlessness.... To the extent materialism means anything at all, it means that what women have been and thought is what they have been permitted to be and think. Whatever this is, it is not women's, possessive. ${ }^{114}$

When MacKinnon espoused these beliefs regarding women's subordination and inauthenticity in a dialogue with Gilligan at the now somewhat infamous "Mitchell Lecture" at Buffalo, Mary Dunlap (a lesbian), who was also a speaker at the event, interrupted. Dunlap said:

I am speaking out of turn. I am also standing, which I am told by some is a male thing to do. But I am still a woman-standing.

I am not subordinate to any man! I find myself very often contesting

112 "Although feminism emerges from women's particular experience, it is not subjective or partial, for no interior ground and few if any aspects of life are free of male power." C. MACKINNON, FEMINIST THEORY OF STATE, supra note 16, at 116.

113 Indeed, her theory of oppression is so complete that it has been described as "metaphysically perfect." Feminist Discourse, supra note 8, at 70 (comment of Ellen DuBois); see also Bartlett, MacKinnon's Feminism: Power on Whose Terms? (Book Review), 75 CALIF. L. Rev. 1559, 1562-63 (1987). MacKinnon herself describes the system of male dominance as "metaphysically nearly perfect." C. MACKINNON, FEMINIST ThEORY OF STATE, supra note 16, at 116 (emphasis added). For a refutation of the inevitability of women's subordination, see C. MACKINNON, FEMINISM UNMODIFIED, supra note 63, at 305-06 n.6 ("If subordination had to be, it would surely be a waste of time to fight for women's rights.").

114 C. MACKinnon, Feminist Theory of State, supra note 16, at 51. 
efforts at my subordination-both standing and lying down and sitting and in various other positions-but I am not subordinate to any man! And I have been told by Kitty MacKinnon that women have never not been subordinate to men. So I stand here an exception and invite all other women here to be an exception and stand. ${ }^{115}$

MacKinnon has subsequently described this event as "a stunning example of the denial of gender," 116 claiming that Dunlap was saying, "all women who are exempt from the condition of women, all women who are not women, stand with me."117 I believe MacKinnon misinterpreted Dunlap's reaction. Dunlap's claim that her experiential reality is often free of male domination was not a denial of the existence of male power, nor a statement that she had risen above other women. It was merely a statement of fact about her reality, a statement she felt compelled to make because MacKinnon's description of "what is" had continued to exclude Dunlap's reality.

Dunlap's reality is not irrelevant to feminist theory. Mary Dunlap, and I, and other lesbians who live our private lives removed from the intimate presence of men do indeed experience time free from male domination. When we leave the male-dominated public sphere, we come home to a woman-identified private sphere. That does not mean that the patriarchy as an institution does not exist for us or that the patriarchy does not exist during the time that we experience freedom from male domination. It means simply that we experience significant periods of nonsubordination, during which we, as women, are free to develop a sense of self that is our own and not a mere construct of the patriarchy. ${ }^{118}$

Nor do we work at this experience of nonsubordination and creation of authentic self to set ourselves apart from other women. We are not asserting a "proud disidentification from the rest of [our] sex and proud denial of the rest of [our] life."119 The struggle is to make nonsubordination a reality for all women, and the reality of nonsubordination in some women's lives is relevant to this struggle. The reality of nonsubordination in lesbian lives offers the "lesbian possibility" as a solution.

At the same time, I believe MacKinnon's claim that all women are subordinate to men all the time is a fair claim upon which to critique the male version of reality, because subordination is such a pervasive experience for women. Her claim gives her a valid standpoint for her critique even though it is not experientially true for all women. Similarly, I

115 Feminist Discourse, supra note 8, at 75 (emphasis in original).

116 C. MacKinnon, Feminism UnModified, supra note 63, at 305-06 n.6.

117 Id.

118 Because I believe the self is developed in relation to others, it matters who the "others" to my self are. If the most intimate "other" is a woman, then the self that I develop in relation to that other is more likely to be woman-identified.

119 C. MacKinnon, Feminism Unmodified, supra note 63, at 305-06 n.6. 
believe Robin West's claim that all women are "connected" to life is a fair claim upon which to critique the male version of the "separation thesis." But I do not believe that the "connection thesis" is true of all women. ${ }^{120}$ Feminist legal theorists must be careful not to confuse "standpoint critiques" with existential reality. And the theorist who has not confused the two must also be careful to prevent her readers from making the confusion.

The problem with current feminist theory is that the more abstract and universal it is, the more it fails to relate to the lived reality of many women. ${ }^{121}$ One problem with much feminist legal theory is that it has abstracted and universalized from the experience of heterosexual women. Consider again Marilyn Frye's challenge to heterosexual academic feminists: "I wish you would notice that you are heterosexual. I wish you would grow to the understanding that you choose heterosexuality . . . that you are and choose to be a member of a privileged and dominant class, one of your privileges being not to notice." 122

Marilyn Frye's challenge was specifically addressed to heterosexual women. When I elected to adopt her challenge at the Women and the Law Conference (and in this essay), I was choosing a "lesbian standpoint" to critique the dominant reality in the same way that some cultural feminists have chosen a "mother standpoint" to critique patriarchy. $\mathrm{My}$ intent was not to convert a roomful of women to lesbianism. It was to raise everyone's self-consciousness about our different "standpoints." Feminist legal theory must recognize differences in order to avoid reinforcing lesbian invisibility or marginality, i.e., impeding "the liberation and empowerment of woman as a group."123

My "lesbian standpoint" enables me to see two versions of reality. ${ }^{124}$ The dominant reality, which I experience as "theirs," includes the following: lesbians are not mothers, all women are dominated by men, male relationships are valuable and female relationships are not, lesbian is a dirty word, lesbians are sick, women who live alone desire men, women who live together desire men, no one knows a lesbian, lesbians don't have families, all feminist legal theorists are heterosexual, all women in this room are heterosexual, lesbians are sex, most women are heterosexual and not lesbian.

120 Nor does West believe it is true of all women; she specifically disclaims such a position. West, supra note 5 , at 71 .

121 See generally E. SPELMAN, supra note 98.

122 Frye, supra note 107.

123 Rich, supra note 104 , at 648.

124 And both versions of reality inform my knowledge of the world. As Nancy Hartsock explains: The concept of a standpoint structures epistemology in a particular way. Rather than a simple dualism, it posits a duality of levels of reality, of which the deeper level or essence both includes and explains the "surface" or appearance, and indicates the logic by means of which the appearance inverts and distorts the deeper reality.

Hartsock, supra note 111 , at 285 . 
By contrast, the reality that I live, the reality I call "mine," includes the following: some mothers are lesbian, many women are lesbian, many lesbian women are not dominated by men, many women do not desire men, lesbian is a beautiful word, lesbians are love, love is intimacy, the heterosexual/lesbian dichotomy is false, all lesbians are born into families, lesbians are family, some feminist legal theorists are lesbian, lesbians are brave.

Why is the lesbian so invisible in feminist legal theory? Why is "my reality" so different from "their reality?" And which reality is true? For the postmodernist, the last question is meaningless. But the first two are not. 